\title{
Employing CBPR to investigate function, utility, and longevity of household filters to improve potable water quality for indigenous peoples at Lake Atitlán, Guatemala: a pilot study with San Pedro de La Laguna
}

\author{
Amber Roegner ${ }^{1} \cdot$ Gerson Ochaeta $^{2} \cdot$ Estuardo Bocel $^{2} \cdot$ Zachary Ogari $^{3}$. \\ Beth Pfotenhaeur $^{4} \cdot$ Eliska Rejmankova $^{1}$ \\ ${ }^{1}$ School of Veterinary Medicine, University of California, Davis, Davis, CA, USA \\ ${ }^{2}$ La Universidad del Valle-Altiplano, Sololá, Guatemala \\ ${ }^{3}$ Kenya Marine and Fisheries Research Institute, Kisumu, Kenya \\ ${ }^{4}$ University of Wisconsin Veterinary Diagnostic Lab, Madison, WI, USA
}

Received: 30 March 2016/Revised: 14 October 2016/Accepted: 27 October 2016/Published online: 7 November 2016

(C) Joint Center on Global Change and Earth System Science of the University of Maryland and Beijing Normal University and Springer-Verlag Berlin Heidelberg 2016

\begin{abstract}
Cyanobacterial blooms at Lake Atitlán in Guatemala threaten and compromise the livelihood and health of local residents. Indigenous Tz'utujil, Kaqchikel, and K'iche' rely directly on lake water for drinking, bathing, cleaning, cooking, and fishing. Nonpoint source runoff and untreated wastewater pumped directly into the lake contribute to high fecal pathogen loads into source waters. Concurrent nutrient loading results in cyanobacterial blooms further compromising water quality. A lakeside municipality facing high rates of childhood gastrointestinal illness volunteered to engage in community-based participatory research (CBPR) to evaluate efficacy, utility, and longevity of filters in households. The filters consistently reduced the risk of coliforms and E. coli in household water drawn from the lake based on World Health Organization guidelines. Household surveys were
\end{abstract}

Amber Roegner

afroegner@gmail.com

Gerson Ochaeta

gersonochaeta@hotmail.com

Estuardo Bocel

estuardobpj@gmail.com

Zachary Ogari

zachzach13@gmail.com

Beth Pfotenhaeur

pfotenhauerwisc@gmail.com

Eliska Rejmankova

erejmankova@ucdavis.edu simultaneously administered through a student leadership group regarding water usage, water quality, and community health. Filters demonstrated ability to reduce high loads of fecal indicators from source waters and ability to remove a cyanobacterial toxin (microcystin) at $10 \mu \mathrm{g} / \mathrm{L}$ in deionized water. Further studies are imperative to determine longevity of use in households and CBPR provides a powerful avenue to test efficacy of a possible intervention while engaging stakeholders and empowering community members with sustainable solutions.

Keywords CBPR - Cyanobacterial blooms · Household filters · Clay vessel $\cdot$ Ceramic candle $\cdot$ Fecal indicators

\section{Introduction}

The situation at Lake Atitlán is not a unique one with indigenous communities around the world disproportionately bearing the burden of socioeconomic and health effects of environmental degradation from human encroachment and population growth (Hoover et al. 2012; Mackey and Liang 2012; O'Donahoo and Ross 2015; Richmond 2013; Saxton et al. 2015). In particular, agricultural expansion and urbanization frequently result in compromised potable water quality and fisheries catch for subsistence communities around freshwater surface bodies impacted by point source and nonpoint source run-off (Bailie et al. 2004; Harvey 2012; Richmond 2013). 
Nutrients, pesticides, herbicides, heavy metals, fecal pathogens all may end up in community source waters inadequately treated in municipalities constrained by resources (Roegner et al. 2014). Cyanobacterial blooms complicate the issue by potentially releasing gastrointestinal and skin irritants along with acute and chronic toxins, further altering water quality and impacting fisheries. They also provide a signal of a stressed ecosystem in dire need of attention. In October through December 2009, a severe cyanobacterial bloom lasting weeks at Atitlán resulted in local, national and international public and government hysteria, miscommunication of health risks to indigenous communities and misplaced blame and burden on those very same communities (Harvey 2012). Compromised surface waters impacting health was not a new finding in the region (Bentley et al. 2004; Laubach et al. 2004). Yet disappearance of the bloom abated hysteria, concern or even attention in the region, despite the potential for nutrient regimes to shift toward toxin-producing cyanobacteria and despite continued risks of municipalities and squatting communities dependent on Atitlán's surface waters (Harvey 2012).

As research with indigenous communities can lack engagement, involve a poorly explained research process and exploit the community for the results of an experimental outcome that may not benefit them (O'Donahoo and Ross 2015), we invited the community to look for solutions to improve water locally prior to the proposal initiation, emphasized their role in the development of the project and stressed our desire to create long term and sustainable solutions over which their communities could take ownership (O'Donahoo and Ross 2015). We aimed to (1) identify locally sourced gravity-fed filters available to communities; (2) document community concerns with water quality and health; (3) determine efficacy and practicality of use of filters in households; and (4) determine ability of those filters to remove both moderate to high risk levels of fecal indicators and the most commonly cited freshwater cyanotoxin, microcystin LR, resistant to environmental degradation and common treatment practices, such as boiling or chlorination.

\section{Background}

\subsection{Health risks from cyanobacterial blooms}

Eutrophication resulting from excessive input of sewage and fertilizer runoff threatens water quality in freshwater ecosystems in worldwide (Carpenter 2008; Conley et al. 2009; Russell and Connell 2009; Smith and Schindler 2009). Increased primary productivity often results in a shift toward harmful bloom-forming cyanobacteria (Funari and Testai 2008; Paerl et al. 2001). Impairment of water quality due to eutrophication can severely threaten local economies and livelihoods (Dodds et al. 2009; Gao and Zhang 2010; Laukkanen et al. 2009). In addition to the potential ability of cyanobacteria to produce a wide variety of potent toxins and allergic compounds (Drobac et al. 2013; Funari and Testai 2008), increasing evidence suggests eutrophication may also result in increased risk of waterborne infectious diseases in dependent and vulnerable populations (Ahmed et al. 2007; Smith and Schindler 2009; Wilhelm et al. 2011). As the incidence of cyanobacterial blooms increases with rising global water temperatures (Paerl et al. 2011; Paerl and Huisman 2008, 2009), management of these blooms must include intervention and prevention strategies that prioritize human and ecological health outcomes, particularly when populations depend directly upon surface waters for potable water with no alternative water source.

\subsection{Challenges faced by household level intervention}

Although clean water is increasingly recognized as a fundamental human right, privatization of public water supplies and political disagreements over responsibility for clean up continues to compromise access to clean water in both developed and developing nations alike (Barbour et al. 2009). According to the World Health Organization (WHO), 1.2 billion people worldwide lack access to clean drinking water, with an additional 2.6 billion lacking adequate sanitation services. The UN estimates that by 2025 , 2.8 billion people will face water scarcity in 48 countries worldwide. While the World Bank, World Trade Organization (WTO), and regional development groups continue to treat water as a commodity, public health concerns at the point of source only increase along with the economic burden placed on the poorest communities. Thus, it is absolutely essential to offer accessible, practical and effective treatment options at point of source for even the poorest of communities (Wright et al. 2004).

\subsection{Point of use (POU) interventions}

In addition to potential health risks presented by source water quality, the actual collection, transport and storage of drinking water can lead to further contamination. In communities without infrastructure for delivery from source to use or without periodic monitoring of initial water treatment or repair of infrastructure, health professionals and pubic health officials now advocate POU interventions through water, sanitation, and hygiene (WASH) infrastructure (Mellor et al. 2014). Traditional recommendations to risk at point of use (POU) have long been recognized to have limitations (Mintz et al. 2001). Boiling effectively 
inactivates many viruses, bacteria, and parasites and is the only POU in widespread use, yet it is often impractical to meet household usage (Clasen et al. 2015b; Sobsey et al. 2008). In addition, boiling concentrates the toxins of concern in this study, and long-term storage presents the challenge of bacterial re-growth. Addition of sodium hypochlorite has proven effective in bacterial load reduction at POU in epidemiological studies (Reller et al. 2003), yet limitations in effectiveness against protozoa, viruses and toxins, in addition to problems with disagreeable odor and taste, limit the comprehensiveness of this treatment option.

While gravity-fed filtrations methods often are distributed in disaster relief situations (Casanova et al. 2012; Loo et al. 2012), increasing evidence suggests that they can provide a long-term sustainable option for regions lacking treatment infrastructure in order to reduce incidence of gastrointestinal disease (Clasen et al. 2015a; Pandit and Kumar 2015). Lower to middle income countries (LMICs) increasingly rely on these technologies to address the declining water quality conditions around the world, but challenges include access, reliability, and consistency of source materials, quality of control and assurance of manufacturing process, proper education of filter use and maintenance, inadequate filter flow rate of capacity, and community and/or household compliance (Clasen et al. 2015b; Sobsey et al. 2008).

A comprehensive review of avenues and barriers to clean water in developing countries (Pandit and Kumar 2015) outlines water quality, guidance values for contaminants and pathogenic microorganisms, and categorical treatment technologies with particular focus on cost and feasibility at POU and should be consulted for a more indepth discussion of this topical area. In brief, options include chemical and natural disinfectants, solar disinfection (SODIS), and gravity-based filtrations (carbon, sand, and clay or ceramic vessel filters). While solar-sourced treatment is low cost and abundant, the duration of treatment before which water becomes permissible to drink and variable performance in disinfection or degradation of contaminants has led into experimentation with the addition of photosensitizers or photocatalysts (such as titanium dioxide) to enhance oxidative processes (Pandit and Kumar 2015). These newer modalities of the technology still warrant field and laboratory investigations against various categories of contaminants. As mentioned dilute sodium hypochlorite is frequently recommended by public health agencies but requires appropriate dosing and often leads to non-compliance as end users complain of the taste and smell. Gravity-based filtration with locally sourced materials can lead to an economical and sustainable approach to treatment, but necessitates careful consideration of the local manufacturing process. In the described study, we aimed to evaluate efficacy of a locally sourced clay vessel gravitation fed filter employed in the household setting and then to compare it to a well-described ceramic candle filter in a controlled setting with environmental waters. Much of the evidence for scaling up on this approach relies on recall data of household reported gastrointestinal disease, yet few field trials have critically at contaminant removal efficacy of various POU options in this household context (Albert et al. 2010; Schmidt and Cairncross 2009).

\subsection{Gravity-fed ceramic or clay POU filters}

Ceramic or clay vessel filters have been fabricated since antiquity from locally sourced clays or porous ceramic medium. While the low-cost ceramic filters can adequately reduce bacteria by $99 \%$ in laboratory conditions, they demonstrate less reliability in field situations (Simonis and Basson 2011). With high specific area, high permeability, and high tortuosity, and the potential to filter to submicron pore size, three main processes are utilized for uniformly shaping porous ceramics: pressing, extrusion and slip casting, but shape of defects depends on processing method and consistency of selected method (Simonis and Basson 2011). Optimization of local manufacturing, quality control and quality assurance of the process becomes paramount for filter longevity in addition to proper use and maintenance within a household. Critical evaluation must include procedure and mixing of filter constituents: source clay, water, and combustible material (corn husk, rice husk, saw dust, etc.) (Servi et al. 2013) and initial standardization of a process for field-testing and laboratory challenge experiments with natural waters.

\subsection{Retention mechanisms of gravity-fed filters}

Field trials and development of relevant model have begun to unearth the mechanisms behind contaminant retention and the implication of the role of selection and processing of source materials, added constituents or other components in performance (Simonis and Basson 2011). Two primary mechanisms are considered important for retention: physical removal and inactivation. Physical removal can include initial pore size exclusion for protozoa, some bacteria, and larger molecules and solid or aggregate formation inside the filter enhancing absorptive processes and properties allowing for retention and potential elimination of smaller bacteria, contaminants, and viruses (Bielefeldt et al. 2009; Simonis and Basson 2011). The application of ionic and nanoscale silver also can further inactivate pathogenic organisms (Bielefeldt et al. 2009). Preliminary studies with ceramic vessels utilized in households for over 4 years and with intermittently used filters demonstrated that removal of $\mathrm{E}$ coli spiked with $106 \mathrm{CFU} / \mathrm{mL}$ doses 
declined with serial spiking and that reapplication of colloidal silver would reverse some of the loss of declining efficacy (Bielefeldt et al. 2009). Further efforts to understand mechanisms of interaction between silver nanoparticles, water characteristics, and ceramic source materials can help to optimize fabrication, use and care to promote longevity, while minimize any potential health risks from released silver (Mittelman et al. 2015).

\subsection{Commercial ceramic candle filters}

First developed in the nineteenth century by Wilhelm Berkefeld to address contamination and subsequent illness from the River Thames in London, various current commercial models perform well in the reduction of turbidity and retention of bacteria in a controlled laboratory setting, if appropriately cleaned and scrubbed periodically, although still contingent upon conditions and load of source water contamination (Chaudhuri et al. 1994; Michen et al. 2011). Operating by similar mechanisms to locally sourced clay or other ceramic vessels (Simonis and Basson 2011), intensive manufacture of these diatomaceous earth (DE)-based filters has been improved in processes such as extrusion and slip casting to allow for consistency of performance of material derived from diatoms of various morphologies and variable natural pore size and now includes incorporation of silver or copper to prevent bacterial growth (Michen et al. 2011). The filters sufficiently retain larger protozoa and inconsistently remove bacteria, depending upon duration and volume of water, with insufficient data available on viruses. Experiments with surrogates (latex colloidal particles) have suggested the importance of adsorption and the role of formation of aggregates for retention of smaller raw water constituents. These complex interactions in natural waters make a lifetime prediction difficult (Michen et al. 2011) and necessitate step-wise research to elucidate exact retention mechanisms and the effect of matrix components in natural waters.

\subsection{Cyanobacterial blooms at Lake Atitlán}

The deepest lake in Central America at $341 \mathrm{~m}$, Lake Atitlán is home to three different Mayan indigenous populations (Tz'utujil, Kaqchikel, and K'iche') dependent upon its surface waters and fisheries for sustenance; situated in the Guatemalan highlands and volcanic in origin, the $130 \mathrm{~km}^{2}$ lake is a source of national pride and a tourist destination (Calderón Barrios 2007). Despite increasing population pressure of over 250,000 people now within the watershed and a booming tourism industry, there is little to no treatment of agricultural and municipal runoff. With the waters of Atitlán dramatically altered by anthropogenic pressures since initial water quality monitoring in the $1970 \mathrm{~s}$ (Corman et al. 2015), blooms began appearing nearly in 2008. The largest thus far occurred in 2009 with cover over half the lake's area for almost 2 months. The blooms have predominantly been formed by Limnoraphis robusta Komárek (also known as Lyngbya robusta) (Rejmánková et al. 2011). While this species does not appear to produce toxins, known toxin producers, including Microcystis aeruginosa and botrys, lurk along the shore and river inlets (Komárek et al. 2013). Increased nutrient loading, particularly of nitrogenous wastes, may alter the balance of the lake and cause these potential toxin producers to proliferate (Rejmánková et al. 2011). Blooms generally occur toward the beginning of the region's dry season (November through April); however, much of nutrient loading likely occurs during the region's wet season (Corman et al. 2015).

\subsection{Community-based participatory research (CBPR)}

Community-based participatory research (CBPR) encompasses a range of approaches in the social, environmental, and health sciences in which researchers attempt to transform and improve scientific endeavors by actively engaging community members in the research process, including defining hypotheses and methodology, implementation of research, and interpretation and dissemination of findings (Balazs and Morello-Frosch 2013; Fraser et al. 2006; O'Fallon and Dearry 2001, 2002). CBPR includes a spectrum from passive community engagement to co-learning and co-production throughout the process. While the term has gained increased traction in recent years as a means to encourage community empowerment, facilitate capacity building, enable exchange between community members and scientists, and link research directly to policy action, recent review has suggested it also has the potential to substantially improve the rigor, relevance and reach of science (Balazs and Morello-Frosch 2013). Rigorous methodologies applicable to source drinking water monitoring and improvement of quality have yet to be delineated (Ford and Hamner 2015). The human health problems related to the deteriorating surface water quality faced by the communities at Lake Atitlán present a challenging situation in which to critically employ and improve these approaches to benefit lakeside communities and scientific engagement, particularly given the persistent challenges faced by implementation of POU interventions within communities. The majority of CBPR has been applied within the social sciences or focused on specific prevention or medical intervention therapies in order to address recognized health disparities (Johansson et al. 2015; Rhodes et al. 2010; Salimi et al. 2012; Spector 2012; 
Weiss et al. 2012). CBPR has the potential to build a foundation of trust upon which sustainable, hypothesis driven solutions can be critically evaluated (Lonczak et al. 2013; Spector 2012; Tobias et al. 2013; Weiss et al. 2012). It can also be used to establish a baseline for surveillance of health risks to particularly disadvantaged communities for which data is absent or scant and generate platform of trust from which to design future studies (Johansson et al. 2015; Spector 2012; Weiss et al. 2012). Yet, care must be taken not to bias scientific results through study design and participant selection (Johnson et al. 2016) while also identifying means for future capacity building such that interventions become sustainable for the targeted communities or populations (Salimi et al. 2012; Weiss et al. 2012). To our knowledge, this study is the first of its kind in attempting to evaluate efficacy of household filters with direct community engagement.

\subsection{San Pedro de la Laguna}

San Pedro is one of four lakeside towns that withdraws drinking water directly from the lake with $85 \%$ of municipal water from the lake and the remaining $15 \%$ from mountains and streams (source: Guatemalan Ministerio de Salud Pública y Asistencia Social, Sanemiento Ambienta, 2013), although numerous subsistence communities around the lake also rely directly on lake waters for drinking, washing, bathing, and fisheries. Prior to the arrival of the Spanish, it was a part of the Mayan Tz'utujil pueblo; Pedro de Alvarado invaded the region in 1524 with the help of the Kaqchikeles and Mexico. Following a series of colonial rulers, missionary Francisco Fray Pedro de Betanozos eventually founded San Pedro Patzununá, with the indigenous name later being dropped. In 1872, it became a part of the department of Quiche. The town has been completely destroyed twice, once by a fire (1824) and then again by an earthquake (1902) (Navichoc Sajquiy 2007), yet evaded the extensive damage experienced at neighboring communities during Hurricane Agatha in 2010.

Situated in the department of Sololá, San Pedro de Atitlán (Fig. 1) is bordered to the northwest by San Juan de la Laguna, to the northeast by the lake itself, to the southeast by Santiago de Atitlán, to the southwest by Chicacao (Suchitepequez) and situated at latitude $14^{\circ} 41^{\prime} 25^{\prime \prime}$ and longitude $91^{\circ} 16^{\prime} 21^{\prime \prime}$, with a total area of $24 \mathrm{~km}^{2}$ at $1610 \mathrm{~m}$ above sea level (Navichoc Sajquiy 2007). Historically, it has divided into four cantones, overlapping in only one location, Chuwasanayii', Pakucha', Chuwakante and Tzanjaay, and the people conserve the names despite the municipality forming five zones with assigned streets and housing (Navichoc Sajquiy 2007). San Pedro was selected for this pilot project to evaluate function, efficacy, and practicality of locally available filters based on (1) perceived willing citizenry; (2) an active youth leadership group; (3) town-elected representatives interested in facilitating project; (4) previous evidence of source lake water contamination; (5) reported elevated levels of gastrointestinal illness, particularly among children less than 5 years old (source: Guatemalan Ministerio de Salud Pública y Asistencia Social, Sanemiento Ambiental); and (6) previous evidence of non-compliance of potable water systems with government mandated chlorination (source: Guatemalan Ministerio de Salud Pública y Asistencia Social, Sanemiento Ambiental). In addition, San Pedro has had a documented history of failed interventions that have suggested that a traditional top down approach will not work (Paul and Demarest 1984) (personal communication with town leaders); indeed, some of the most effective organization and change for Guatemala indigenous citizens has come about by decentralization and greater responsibility at the municipal level, enabling them to address issues related to quality of land and water health through their own modes of organization (Rasch 2012).

\section{Methods}

The study approach involved engaged communication between scientists and specialists from the US, Guatemalan university students, elected town representatives (forming the local Consejos Comunitarios de Desarrollo Urbano y Rural, COCODES), business owners, community members, educators, and even high school students (Los Niños del Lago). Initial design and aims resulted from discussions with listed stakeholders and distribution and filter education became a combined effort, later followed by sample collection. Figure 2 illustrates the translational approach as a means to empower community members to enable the longitudinal portion.

\subsection{Filter selection and specifications}

Only two locally available filters (Table 1; Fig. 3) readily available to communities in the region were identified at the time of the initiation of the study. The ceramic pot filters (Ecofiltro) were purchased from Ecofiltro S.A., a Guatemalan-based social business with the aim of providing clean water for rural families; the prototype was invented in 1981 by a Guatemalan chemist and includes a clay vessel (maximum capacity $20 \mathrm{~L}$; manufacturer flow rate of $1-2 \mathrm{~L} / \mathrm{h}$ ) and a catchment vessel. The clay is locally sourced (Rabinal Baja Verapaz) and ground, mixed with sawdust $(0.54 \mathrm{~kg}$ sawdust utilized $/ 4.5 \mathrm{~kg}$ clay, $1.8 \mathrm{~L}$ water), extruded, pressed and baked, after which the vessel is impregnated with colloidal silver (sourced from Peten, unspecified concentration) prior to packaging and 


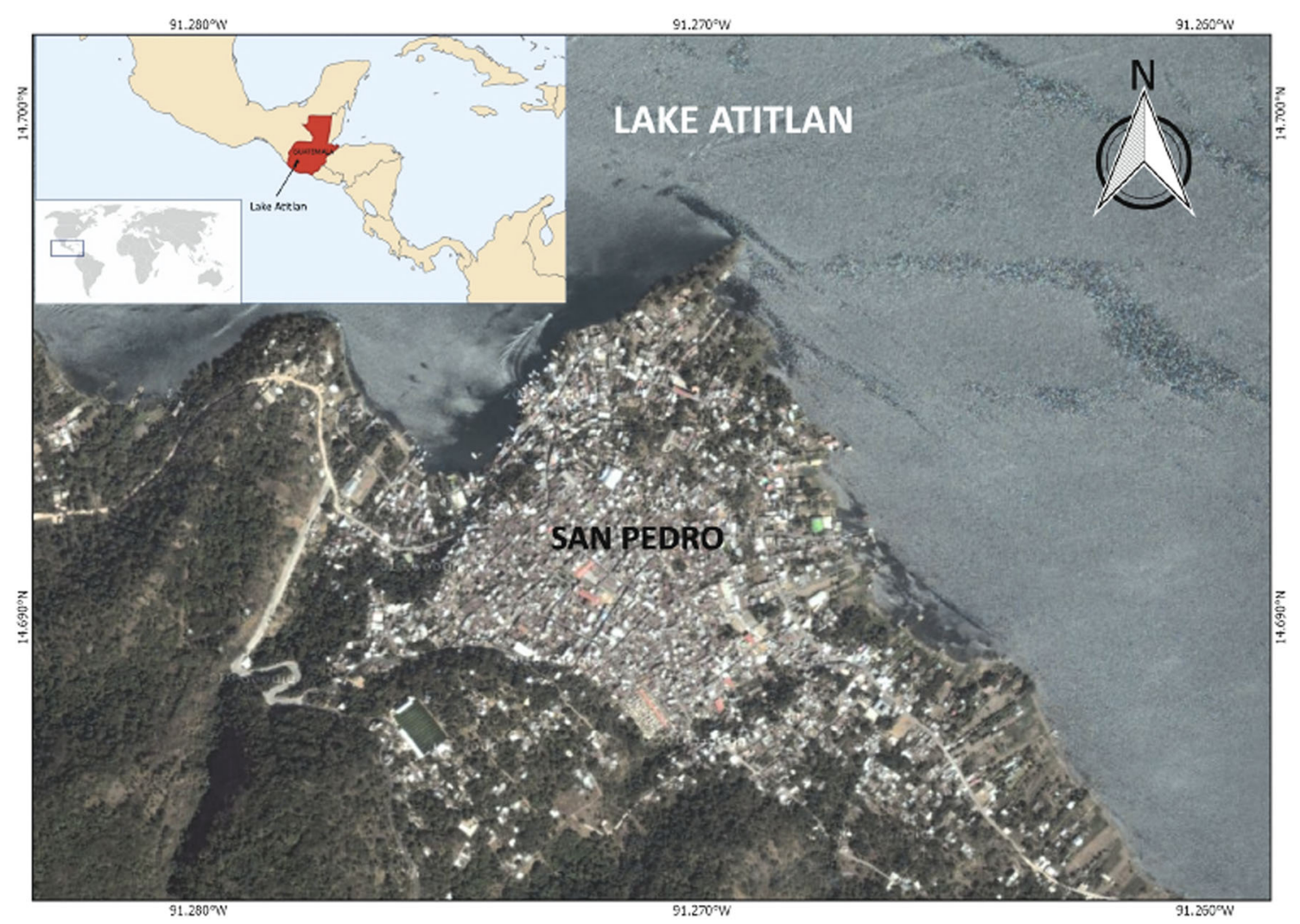

Fig. 1 Map illustrating study site within Guatemala and satellite of immediate land use in San Pedro de La Laguna

Fig. 2 CPBR approach employed at San Pedro de La Laguna to address health risks from natural waters used as potable source

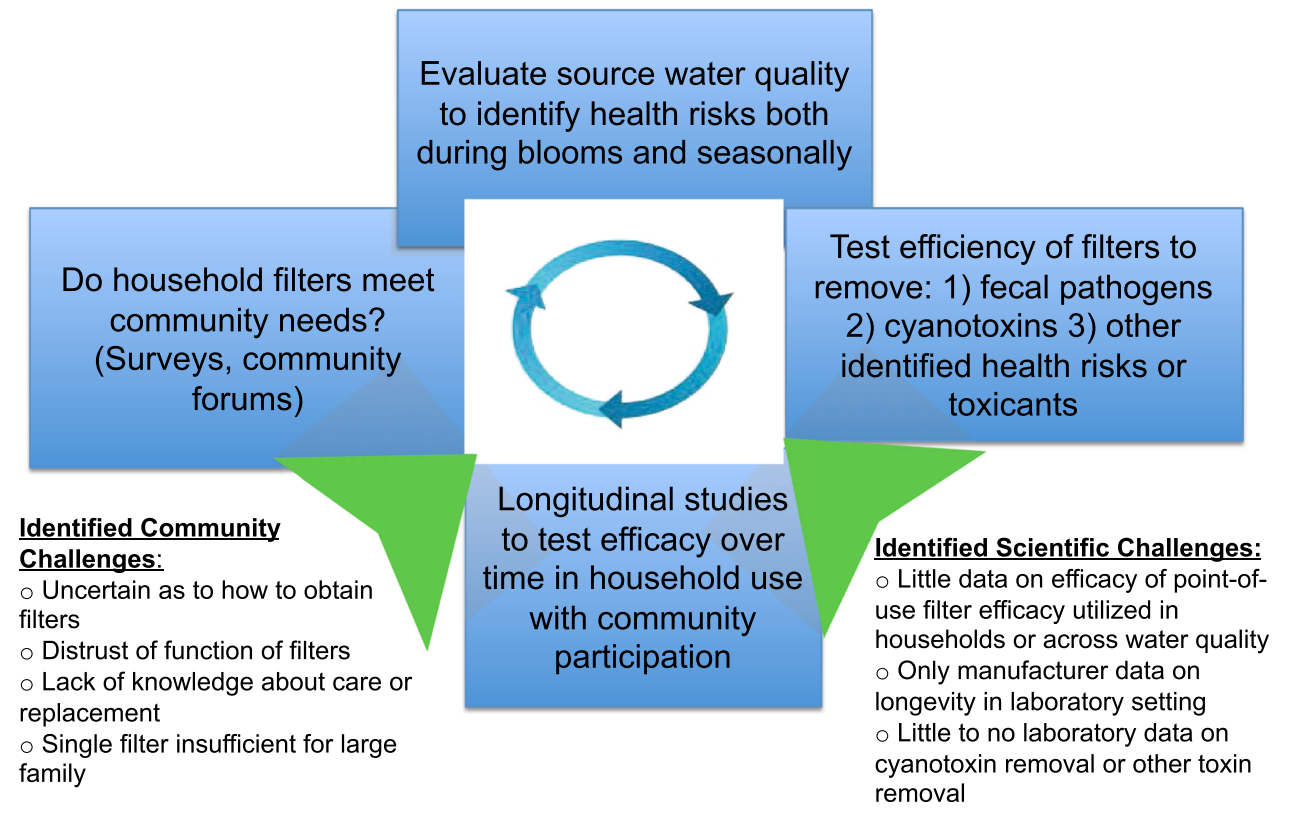

Utz Ja' filters were not immediately available for purchase or distribution at the time of the initiation of the study with communities, but later were obtained for laboratory-based studies. The Guatemalan-based distributor (Bombagua) obtains British Berkefeld ceramic candles impregnated with silver and with an activated charcoal core 
Table 1 Side-by-side comparison of distributor reported filters employed in the study

\begin{tabular}{llllll}
\hline $\begin{array}{l}\text { Filter brand } \\
\text { name }\end{array}$ & Cost & Flow rate & $\begin{array}{l}\text { Filter } \\
\text { capacity } \\
(\mathrm{L})\end{array}$ & $\begin{array}{l}\text { Pore size } \\
(\mu \mathrm{m})\end{array}$ & Materials \\
\hline Ecofiltro & $\begin{array}{c}300 \text { Q. for unit; 200 Q. for } \\
\text { filter replacement }\end{array}$ & $1-2 \mathrm{~L} / \mathrm{h}$ & 20 & 0.6 to 0.3 & Locally sourced clay, sawdust, colloidal silver \\
$\begin{array}{l}\text { Utz Ja" (Good } \\
\text { Water) }\end{array}$ & "Humanitarian price" & $\begin{array}{c}\text { Not available from } \\
\text { manufacturer }\end{array}$ & 20 & 0.9 & $\begin{array}{c}\text { British Berkefeld (ceramic shell, activated } \\
\text { carbon core, colloidal silver) }\end{array}$ \\
\hline
\end{tabular}

Fig. 3 Schematic depiction of two gravity-fed household filters: Ecofiltro and Utz Ja

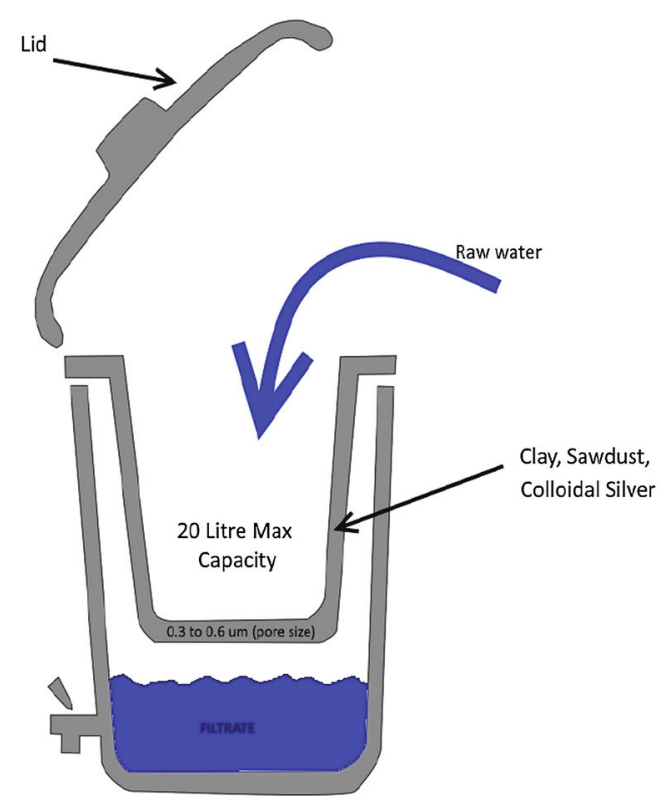

Ecofiltro

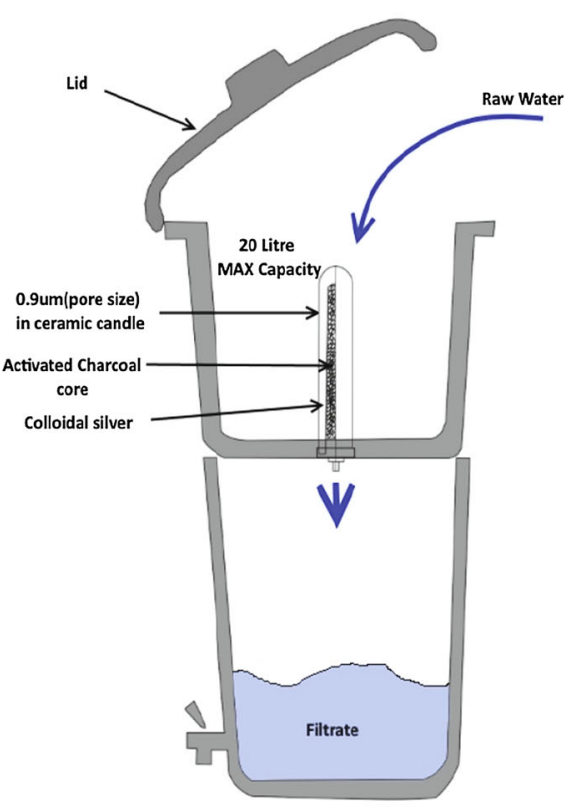

Utz Ja' and certified by NSF International, WRAS, and ISO standards; the filters are certified with a fore size of $0.9 \mu \mathrm{m}$. The filter set up is locally constructed and is composed of two stacked food-grade virgin-plastic five gallon buckets with the filter fitted to the inside of the upper bucket for gravity flow (Fig. 3).

\subsection{Filter distribution and follow-up}

Given a failed previous distribution, community interest and ready availability in the region for purchase, clay pot vessels were selected for household distribution in San Pedro. Town COCODES helped identify 20 households equally distributed across the cantones Chuwasanayii', Chuwakante and Tzanjaay for participation in the preliminary longitudinal study. Town educators aided with filter distribution and translation between Spanish and Tzutzujil' during explanation of intended study design and participation. Explanation of filter design, set up and maintenance was translated; informational handouts on the filter function, aims of study and sample collection were provided (Fig. 4).

Several days later, trained student groups visited the households to confirm proper set up and make the first collection of water at household source and post-filtration. Students educated households on proper water collection to avoid sample or filter contamination, and confirmed a subsequent visit for an interview on water usage, household health, treatment options, and overall perceptions of water quality.

\subsection{Longitudinal studies on efficacy of clay pot vessels in San Pedro households}

Following distribution in January 2014, tap or source water (raw) and permeate samples were collected every 6 weeks. Initially, students made the sample collection and community leaders organized collection and transport across the lake by boat. Samples were kept in a cooler on ice during transport and were evaluated within 24 h. Nalgene 

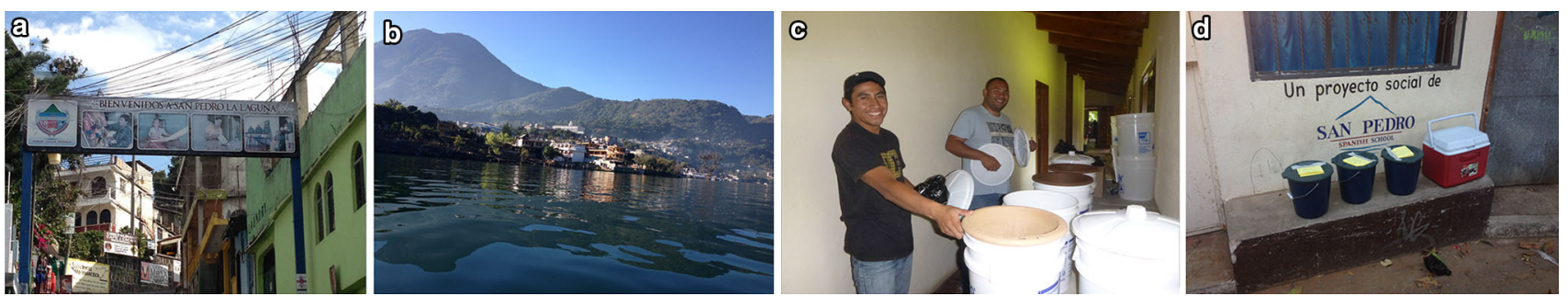

Fig. 4 San Pedro pier at entry (a); shores of San Pedro from the lake (b); Guatemalan students demonstrate filter set up in study initiation (c); student organization serving as central collection point for samples from cantones (d)

HDPE $250 \mathrm{~mL}$ wide-mouth collection bottles with polypropylene screw were purchased from Sigma-Aldrich (St. Louis, MO, USA) and labeled as raw water and permeate with household assigned number. Between sample collection and analysis, bottles were washed and autoclaved and re-used for the same sample site collection. Coliform and E. coli counts were made based on the 15-tube dilution Colilert (Idexx Laboratories, USA) by trained Guatemalan university students. In brief, five replicate $10 \mathrm{~mL}$ tubes were prepared with the Colilert substrate for each sample at the following $100 \mathrm{~mL}$ prepared dilutions: none, 1:10, and 1:100. The inoculated tubes were incubated at $35 \pm 0.5{ }^{\circ} \mathrm{C}$, for $20-24 \mathrm{~h}$ according to the package insert instructions. The samples were then examined for color change by coliform enzyme (yellow) and fluorescence evaluated using a 6-W UV lamp compared to controls. The most probable number (MPN)/ $100 \mathrm{~mL}$ of total coliform bacteria (metabolizing ONPG with enzyme $\beta$-galactosidase) and $E$ coli (metabolizing MUG with enzyme $\beta$-glucuronidase) in each sample was then determined from the table in Standard Methods for the Examination of Water and Wastewater, 18th ed. (APHA, AWWA, WEF).

\subsection{Challenge experiments with locally available filter types with raw lake waters}

Both locally available filters were utilized for controlled laboratory experiments. Ceramic candle with activated carbon and clay pot vessel filters were evaluated for efficacy of removal of fecal coliforms and E. coli, from raw waters at intake points for two separate lakeside municipalities (San Pedro and Santa Catarina), employing the 15-tube dilution method as depicted in Fig. 5. Control 5 -gallon plastic buckets were employed to determine percent removal. Brand new filters were obtained from distributors, and used filters (greater than 1 year old) were obtained from communities to evaluate longevity of filters under identical conditions. Average filter rates were calculated as preliminary discussions with community members had indicated filter rates present a challenge in household water usage. In addition, a baseline survey of fecal indicator counts (FIC) in various environmental waters around the lake was taken to give a reference point for comparative water quality of the two utilized source waters with Santa Catarina withdrawing mountain spring water from a well and San Pedro depending mostly on lake sourced water.

\subsection{Challenge experiments with locally available filters with tertiary treated waters in US}

Following performance testing in country, clay pot vessel $(n=3)$ and ceramic candle with activated carbon $(n=3)$ were brought back to the US and challenged with tertiary pond water with FIC at higher levels recorded in other regions of the lake. Experimental procedures were identical.

\subsection{Challenge filter experiments with microcystin LR}

Both filter types were challenged with $10 \mu \mathrm{g} / \mathrm{L}$ microcystin LR spiked into deionized water. Microcystin-LR was purchased from Enzo Life Sciences (Farmingdale, NY); Microcystins were detected using the Envirologix QuantiPlate $^{\mathrm{TM}}$ (Portland, Maine) ELISA method and later concentrations were verified with HPLC-MS/MS detection. The Molecular Devices SpectraMax Plus 384 Microplate Reader (Sunnyvale, CA) was utilized to read the QuantiPlate $(\mathrm{LOD}=0.1 \mu \mathrm{g} / \mathrm{L})$ prepared according to manufacturer directions at $450 \mathrm{nM}$.

An EVOQ Elite model triple quadrupole mass spectrometer according to Bruker guidance material for LC-MS/ MS analysis of microcystins in drinking water (detection limit, $0.05 \mu \mathrm{g} / \mathrm{L}$ ), utilizing ACE Excel C18 columns $(100 \mathrm{~mm} \times 2.1 \mathrm{~mm})$ with an injection volume of $50 \mu \mathrm{L}$ at a flow rate of $0.4 \mathrm{~mL} / \mathrm{min}$ with two mobile phases $(A=$ water with $0.1 \%$ Formic acid, $B=$ Acetonitrile). The EVOQ Elite (Bruker, USA) was operated in ESI $(+4500 \mathrm{~V})$ in multiple reaction monitoring (MRM) with optimized MRM transitions calibrated with microcystin standards obtained from Sigma-Aldrich (St. Louis, Missouri), yielding highly reproducible curves ranging between 0.5 and $100 \mu \mathrm{g} / \mathrm{L}$. 

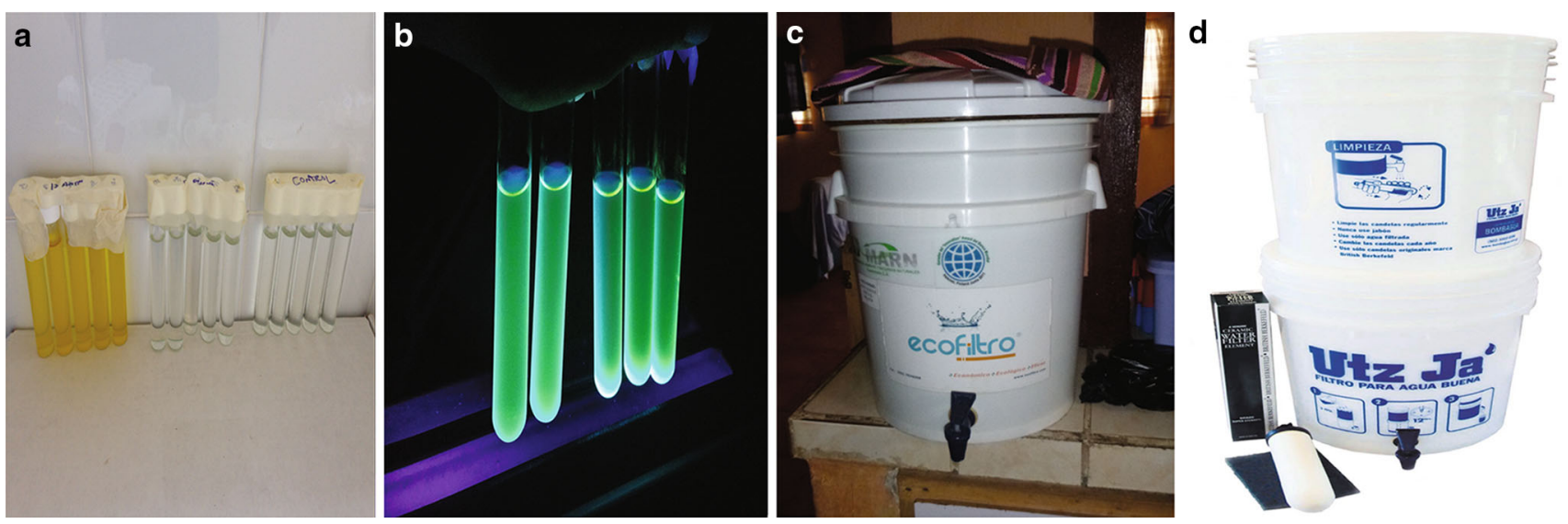

Fig. 5 Colilert 15-tube dilution method depicted (a); positive fluorescence dilution for E. coli (b); clay pot vessel filter, Ecofiltro (c) ceramic candle with activated carbon (Utz Ja) (d)

\subsection{Data analysis}

Comparisons in efficacies between filter types were made using one-way ANOVA $(p<0.05)$ on specific sampling events and for averages. For household filters, both total number and\% households on each sampling dates in each category of risk from FIB were calculated according to World Health Organization (WHO) guidelines of mild, moderate, and severe risk assigned to $<10,10-100$, and $>100 \mathrm{MPN} / 100 \mathrm{~mL}$, respectively.

\section{Results and discussion}

\subsection{Filter distribution, household retention, and sample collection}

Given past documented failed attempts to improve health outcomes at San Pedro de Atitlán (Paul and Demarest 1984), investigators and community leaders underscored the paramount importance of community investment from initiation of any POU intervention. Investigators and community leaders and members continued to emphasize the importance of this bi-directional participation and communication for sustainability.

Twenty filters were distributed evenly among three cantones of San Pedro de Laguna. Chuwacante, Chuasanahí, Tz'anjaay. Pakucha' did not participate due to loss of follow-up with the elected official, emphasizing the importance of multiple levels of engagement and leadership.

Eighteen families were retained throughout the course of the study, while one household joined already having a clay pot vessel in use. Members of the student group, Los Niños, collected the first set of household water samples and verified proper filter set up in households, while community engagement allowed for continued sample collection over the 6-month period; the operational change did not impact the reliability of sample collection, but investigators had to trust that engaged community members were not contaminating the samples. For longer-terms studies, continued engagement through sharing of results and emphasis of the role of contribution of the community on the quality of research will be paramount; quality control samples should be pursued in a way to not create a sense of distrust.

Although a small sample size, the $90 \%$ retention rate throughout the course of the study indicates the potential power and scientific rigor afforded by CBPR to POU intervention studies, given generally reported retention rates (Clasen et al. 2015b; Sobsey et al. 2008). Since longitudinal POU filter intervention investigations have rarely lasted more than a year, this type of CBPR intervention study could be utilized to field test models that have indicated that clay pot vessels could last up to 3 years with proper maintenance and household compliance in use (Mellor et al. 2014). Communities could aid in more mechanistic focused studies to improve overall filter design.

\subsection{Implications for CBPR in design}

Recent work has focused on systematic evaluation of the influence of source local clays, manufacturing processes and the further incorporation of silver into the manufacturing process. Mineral composition, silver sorption/desorption and strength all modulate filter durability and use. Clay with traces of crystalline albite or crystalline pyroxene demonstrates better sorption of silver particles. The application of silver nanoparticles results in slower desorption and thus increased longevity than ionic silver (Oyanedel-Craver et al. 2014). Other work has looked at 
cost effective ways to apply silver nanoparticles through a low cost soak and-dry method as opposed to spray application (Larimer et al. 2010). As technology advances and our understanding of mechanisms of removal improve, efforts to keep manufacturing simple and low cost must be streamlined and integrated into both modeling and laboratory challenge studies, as well as piloted with the aid of communities.

Filter performance includes flow rate or a consideration of the amount of water that the filter can produce for a household. A recent model includes evaluation of water level over time, instantaneous volumetric flow rate of filtrate, and cumulative volume of water produced as influenced by vessel shape and frequency of filling. The model predicts that more frequent filling (up to three times a day) can increase the amount of water generated (up to 45\%) over the course of the day and that a narrower, tall filter will outperform a wide, shallow vessel, all other characteristics being equal (Schweitzer et al. 2013). Field-based trials implementing suggestions in use resulting from models can validate the specific model recommendations; these trials necessitate active, household or community participation. CBPR provides an avenue for this active participation to improve not only end-use but filter design.

A recent study with 400 randomly selected subsistence farmer households in Nyanza Region, Kenya, is one of the few field studies that have incorporated a side-by-side comparison of POU treatments coupled with measures of performance in FIB removal and a close look at user preferences and needs (Albert et al. 2010). Households evaluated dilute hypochlorite solution, porous ceramicbased filtration and combination of flocculant-disinfectant powder mixtures. Greater elective use of dilute hypochlorite and filter resulted compared to the combined methods. Disinfectant methods outperformed the filters in actual use, though household preferred the filtration method. Other studies have suggested that although effective when given at the appropriate dilution, end users dislike the odor and taste associated with chemical disinfectants and eventual non-compliance ensues (Mintz et al. 2001).

\subsection{Household survey results}

Sixteen surveys were successfully completed with distribution as follows: six households in Chuwacante, four in Chuasanahí and six in Tz'anjaay. The two remaining participating households were not available on initial date of survey completion and follow-up for completion was lost. Participants and community members suggested in the future conducting similar surveys at a central location and around a community event, although it might bias individuals and households recruited. The average household size was $5.8 \pm 2.5$ individuals, with a range of two to ten individuals in a household. The majority of respondents were women $(75 \%)$, as the party most responsible for household water usage. The majority of households reported municipal sources of water (a combination of lake and spring water), while three households reported taking the water directly from the lake $(\sim 16 \%)$ and one reporting a mountain source, although this remains unclear as to whether the participant was referring to municipal source. All households used the water for personal hygiene, with the majority also indicating use in cooking and washing clothes and approximately one third reported use in rinsing fruits and vegetables and gardening. Approximately half of the households had utilized some form of treatment previously, including two reporting chlorination, five reporting previous filter use, and one using a coarse cloth filter at tap source. Most households (68\%) reported having to purchase large bottles of water for use, with the majority (73\%) of these saying a large bottle lasted 2-3 days. The most commonly reported quantity of daily household usage was one barrel of water (54\% of those reporting). The majority of households reported using their own storage method for potable water use $(73 \%)$. As for the overall quality assessment of the water source, two households reported very good water quality, seven good water quality, five acceptable water quality, and two extremely poor.

Twenty percent of reporting households reported illnesses that they associated with water sources with $25 \%$ of those cases involving gastrointestinal illness, $19 \%$ reporting fevers, and only one reporting vomiting and diarrhea. Treatments included going to the doctor, medicinal plants, or western medications. The average number of hospital visits per household reported was $2.5 \pm 1.3$ per year, with only $25 \%$ of households reporting preventative medicine visits and 69\% reporting emergency visits to the hospital. Respondents claimed that during November and December, changes in seasons, May and June and periods of cold being the most common times for illness. Interestingly, the November through December time frame overlaps with typical periods in which cyanobacterial blooms occur. Four households reported their animals utilizing the same water source with two of those reporting animal illnesses potentially associated with water source. All respondents reported desire and interest to learn more about water quality as related to health.

Fifty percent of households described previous filter use, followed by $13 \%$ heads of households reporting chlorination, with $86 \%$ reporting the taste of chlorination being bothersome. Sixty three percent responded that a color change in water source (associated with potassium permanganate treatment) would bother them. All except two households claimed to boil some water, with one of those using a filter. The majority of households $(88 \%)$ indicated that they would not have a problem with more than one 
Table 2 Mean raw water and permeate levels of coliforms and E. coli across San Pedro canton households over 6 months

\begin{tabular}{lllcl}
\hline $\begin{array}{l}\text { Location } \\
\text { Units }\end{array}$ & $\begin{array}{l}\text { Raw water coliforms } \\
\text { MPN/100 mL }\end{array}$ & $\begin{array}{l}\text { Permeate coliforms } \\
\text { MPN/100 mL }\end{array}$ & $\begin{array}{l}\text { Raw water E. coli } \\
\text { MPN/100 mL }\end{array}$ & $\begin{array}{l}\text { Permeate E. coli } \\
\text { MPN/100 mL }\end{array}$ \\
\hline San Pedro & $332.9 \pm 155.8$ & $96.3 \pm 38.2$ & $91.3 \pm 12.1$ & $6.6 \pm 1.7$ \\
Chucawante & $221.0 \pm 200.8$ & $32.9 \pm 78.1$ & $68.9 \pm 65.9$ & $3.6 \pm 2.5$ \\
Chuasanahí & $391.1 \pm 282.1$ & $88.4 \pm 93.8$ & $44.3 \pm 33.5$ & $6.7 \pm 4.4$ \\
Tz'anjaay & $348.7 \pm 149.0$ & $26.4 \pm 42.6$ & $106.2 \pm 136.8$ & $2.8 \pm 1.1$ \\
\hline
\end{tabular}

treatment methods and $93 \%$ had no issues with the idea of filter maintenance. None raised issues with the idea of cleaning the filters. The majority of households ( $86 \%)$ were willing to buy replacement parts or candles. The responses corroborate well with recent analysis that ceramic filters provide a sustainable socioeconomic solution for POU filtration in resource-restricted regions of the world (Mellor et al. 2014; Ren et al. 2013). All respondents associated water quality with life and good health, with all respondents identifying contamination as impacting water quality the most. Forty three percent of respondents identified community-based groups as doing something to address water quality, while only one respondent identified a regional government entity taking action. Respondents suggested ways to address water quality including reducing contamination $(88 \%)$, collaboration, education, and selforganization. All households expressed interested in continued participation and in the link between water quality and health. Filter use did not seem burdensome or difficult for the families, although larger-sized families indicated one filter was insufficient to meet water usage. The main obstacle to continued use was uncertainty as to where to acquire replacement parts once the life span of the filter expired, consistent with previous work citing lack of availability of replacement parts as the single largest obstacle to sustainability (Mellor et al. 2014).

\subsection{Longitudinal studies on efficacy of FIB removal by household filters in San Pedro}

Table 2 provides average raw water and permeate FIC across all households and divided by canton. The average raw water contamination levels across all sampling dates and all samples for coliforms and $E$. coli were $333( \pm 156)$ MPN/100 mL and $91( \pm 69)$ MPN/100 mL, respectively, a severe ( $>100 \mathrm{MPN} /)$ and moderate level (10-100 MPN/ $100 \mathrm{~mL}$ ) of risk to human health, according to World Health Organization (WHO) guidelines. These levels were comparable in terms of fold risk to human health with previously collected data of levels in San Pedro potable source waters of $240 \mathrm{MPN} / 100 \mathrm{~mL}$ of both coliforms and E. coli in August 2010 (unpublished data) and later by a regional monitoring agency in July 2013 (AMSCLAE Annual Monitoring Report). During the course of this entire study, TN at the center of the lake averaged $87.5 \mathrm{ppb}( \pm 18.3)$, while TP averaged 28.7 ( \pm 8.8$)$. Dissolved oxygen $(\mathrm{mg} / \mathrm{L})$ in the near shore environment where intake for municipal water occurs was typically around $7.2 \mathrm{mg} / \mathrm{L}, \mathrm{pH}$ typically around 8.8 , and temperature at 22.6 $( \pm 1.2)$ (personal communication with local monitoring organizations, unpublished data). Water quality parameters, including $\mathrm{pH}$, turbidity, temperature, and dissolved oxygen could not be monitored at source locations given the resources of this study, but the role of these parameters in efficacy of filter performance should be considered in the future.

There was considerable variability in raw FIC, suggesting potential variability in actual potable water source or in infrastructure for delivery (piping to houses, initial container contamination); it is less likely that contamination occurred during sample collection as post-filter samples would demonstrate considerable variability, as well. No significant difference could be determined between cantones, although a more robust sample size should be obtained to further investigate regional differences due to existing infrastructure or discrepancies in household practices and knowledge base. Permeate FIB were substantially reduced with post-filter $E$. coli counts consistently reduced to mild risk of health effects. E. coli and coliforms typically range between 1 and $2 \mu \mathrm{m}$ in size; thus size exclusion becomes the most likely mechanism by which these organisms are being removed from raw water, though the antimicrobial properties of silver may provide additional contribution and prevent re-growth. In addition to emphasizing the proper cleaning and maintenance of these filters, end users were encouraged to keep the vessel out of the sun and allow any sodium hypochlorite treated water to stand in an open bucket prior to pouring through the filter.

Efforts were made to inform households with substantially high raw water loads to evaluate potential sources of contamination in house and to employ an additional filtering step through a cloth to reduce turbidity and improve efficacy of filtering. Table 3 shows mean raw and permeate FIC across households by sampling event; considerable variability in sampling events across time periods can be appreciated so that no correlation with increased risk at specific time points could be determined. Future investigations are needed to tease apart the cause of variability 
Table 3 Mean raw water and permeate levels of coliforms and E. coli across households per sampling event

\begin{tabular}{|c|c|c|c|c|}
\hline \multirow[t]{2}{*}{ Sampling dates } & \multicolumn{2}{|c|}{ Coliforms (MPN/100 mL) } & \multicolumn{2}{|c|}{ E. coli $(\mathrm{MPN} / 100 \mathrm{~mL})$} \\
\hline & Raw water & Permeate & Raw water & Permeate \\
\hline 16-Jan & $12.1 \pm 5.7$ & $2.4 \pm 0.7$ & $5.0 \pm 4.1$ & Not detectable \\
\hline 27-Feb & $344.5 \pm 505.7$ & $30.2 \pm 74.2$ & $74.0 \pm 212.2$ & $3.1 \pm 4.9$ \\
\hline 10-Apr & $318.9 \pm 531.9$ & $20.6 \pm 57.7$ & $28.9 \pm 84.9$ & Not detectable \\
\hline 22-May & $303.2 \pm 539.3$ & $2.6 \pm 1.3$ & $4.5 \pm 4.4$ & Not detectable \\
\hline 18-Jun & $47.8 \pm 81.6$ & $17.3 \pm 59.4$ & $11.7 \pm 20.0$ & Not detectable \\
\hline
\end{tabular}

a Method detection limit was $1.8 \mathrm{MPN} / 100 \mathrm{~mL}$
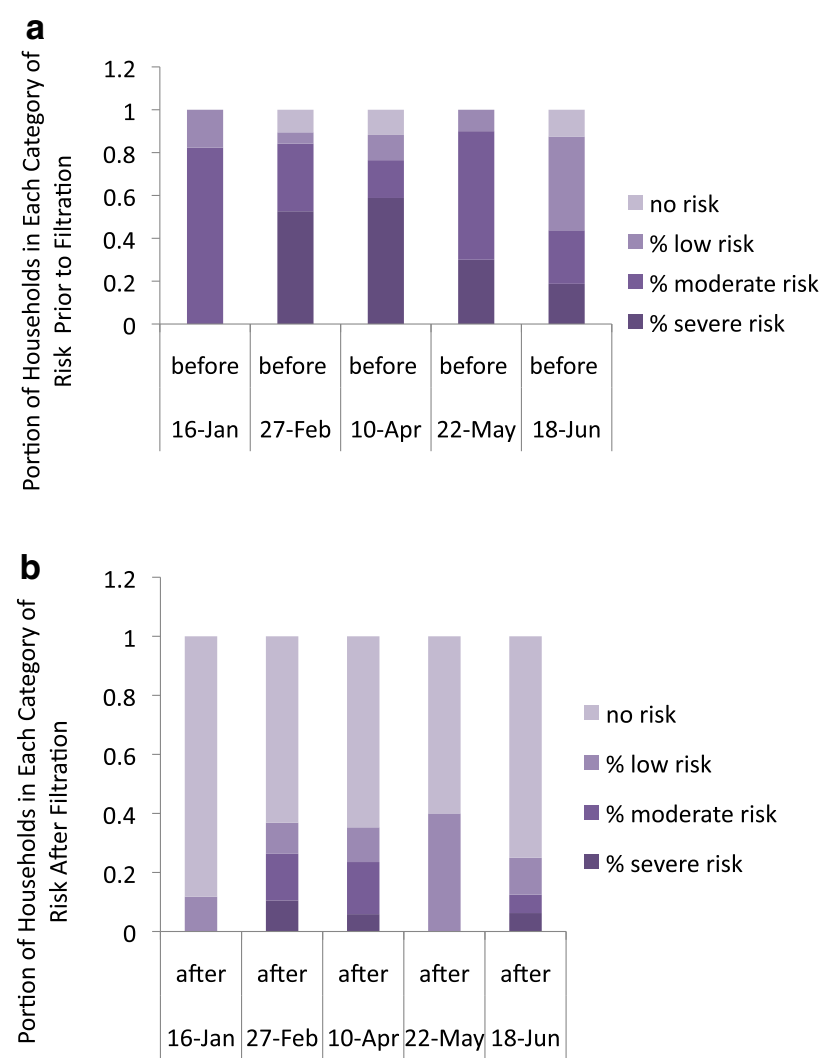

Fig. 6 Raw water (a) and permeate (b) household level risk of coliforms based upon WHO categories by proportion. WHO categories of mild, moderate and severe were assigned to $<10$, 10-100, and >100 MPN/100 mL, respectively

between households and to determine if temporal fluctuations in risk exist at point of intake from the lake.

World Health Organization (WHO) categories of mild, moderate, and severe risk based on MPN, given to $<10$, 10-100, and $>100 \mathrm{MPN} / 100 \mathrm{~mL}$, respectively, were employed to evaluate over function of filters by household. The proportion of households in each category both raw and permeate filter are depicted in Fig. 6 for total coliforms and in Fig. 7 for E. coli.

Employment of the filter substantially reduced the number of households in severe and moderate risk categories. In the case of $E$. coli, only one sampling date
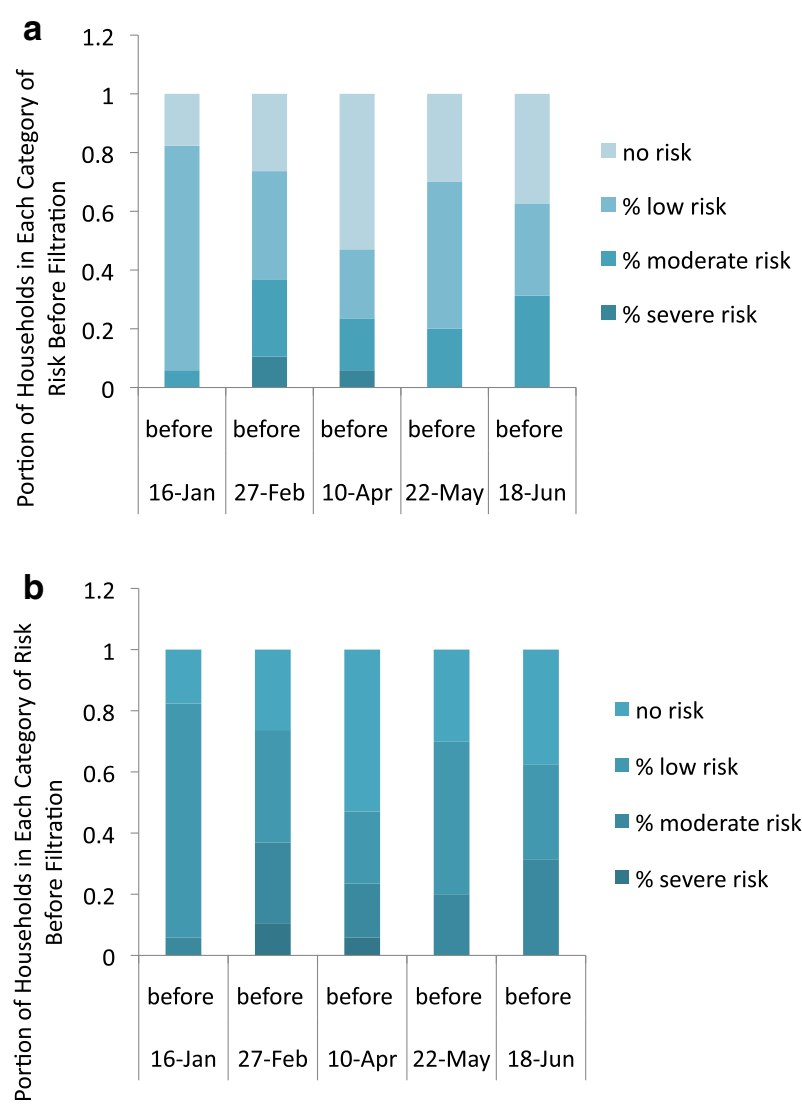

Fig. 7 Raw water (a) and permeate (b) household level risk of E. coli based upon WHO categories by proportion. WHO categories of mild, moderate and severe were assigned to $<10,10-100$, and $>100 \mathrm{MPN} /$ $100 \mathrm{~mL}$, respectively

(February 27) had break through with one household still having severe risk permeate and three more having moderate risk permeate. While these findings confirm previous work citing effective POU removal of fecal indicator bacteria (FIB) by clay vessel filters when properly used and maintained, they reinforce the importance of environmental temporal and spatial studies in complement with longitudinal household studies to determine periods of most risk of source waters in order to make recommendations during those periods for additional treatment methods or protocols, adding a pre-filtration step such as boiling or 
cloth filtration to reduce turbidity and improve efficacy of filters, a second filtration step (another filter), or a postfiltration treatment, such as chlorination or boiling (Mellor et al. 2014; Mintz et al. 2001; Sobsey et al. 2008). Further investigations should include efficacy of retention of smaller bacteria and viruses.

\subsection{Controlled studies comparing filter types with various environmental waters}

Prior to in-country testing of filters with lake and mountain spring waters, challenge experiments were carried out in the US with clay pot vessels, ceramic filters with activated carbon, and sand filters to train Guatemalan university students in experimental design and familiarize them with the FIC methods, utilizing the 15-tube dilution method. Filters were filled with $8-10 \mathrm{~L}$ for 3 days with tertiary wastewater depending upon carrying capacity on site at University of California.

Davis wastewater treatment plant and left for $24 \mathrm{~h}$ prior to sample collection. Control five gallon plastic buckets were also left on site. Clay pot vessels consistently outperformed both the ceramic filters and sand filters on all 3 days with removal of $97.9 \%( \pm 2.6 \%)$ of coliforms and $87.9 \%( \pm 5.1 \%)$ E. coli. Ceramic filters averaged a removal of $88.3 \%( \pm 7.1 \%)$ of coliforms and $60.7 \%( \pm 5.0 \%)$ E. coli, followed by sand filters with $56.7 \%( \pm 16.4 \%)$ coliform removal and $75.6 \%( \pm 14.2 \%)$ E. coli. The particular brand of ceramic filters utilized in this experiment had an extremely slow filtration rate (three times slower than other filters) and were prone to breakage. The sand filters were inconsistent with one of the three filters experiencing break through on day 1 of the experiment. Although not achieving $>90 \%$ removal of $E$. coli, the clay pot vessel filters significantly ( $p<0.05$, ANOVA) outperformed other filter methods in FIB removal as demonstrated in Fig. 8. Although source water quality was not documented at the time, compromised water quality parameters such as increased turbidity, variable $\mathrm{pH}$, and other constituents likely contributed to filter break through.

In country, new ceramic candles with activated carbon $(n=3)$ and clay pot vessels $(n=3)$ were obtained from
Fig. 8 Coliform and E. coli retention from tertiary wastewater by three filter types. Clay vessels significantly outperformed both the ceramic filters and sand filters on all 3 days for removal of total coliforms $(P<0.05)$
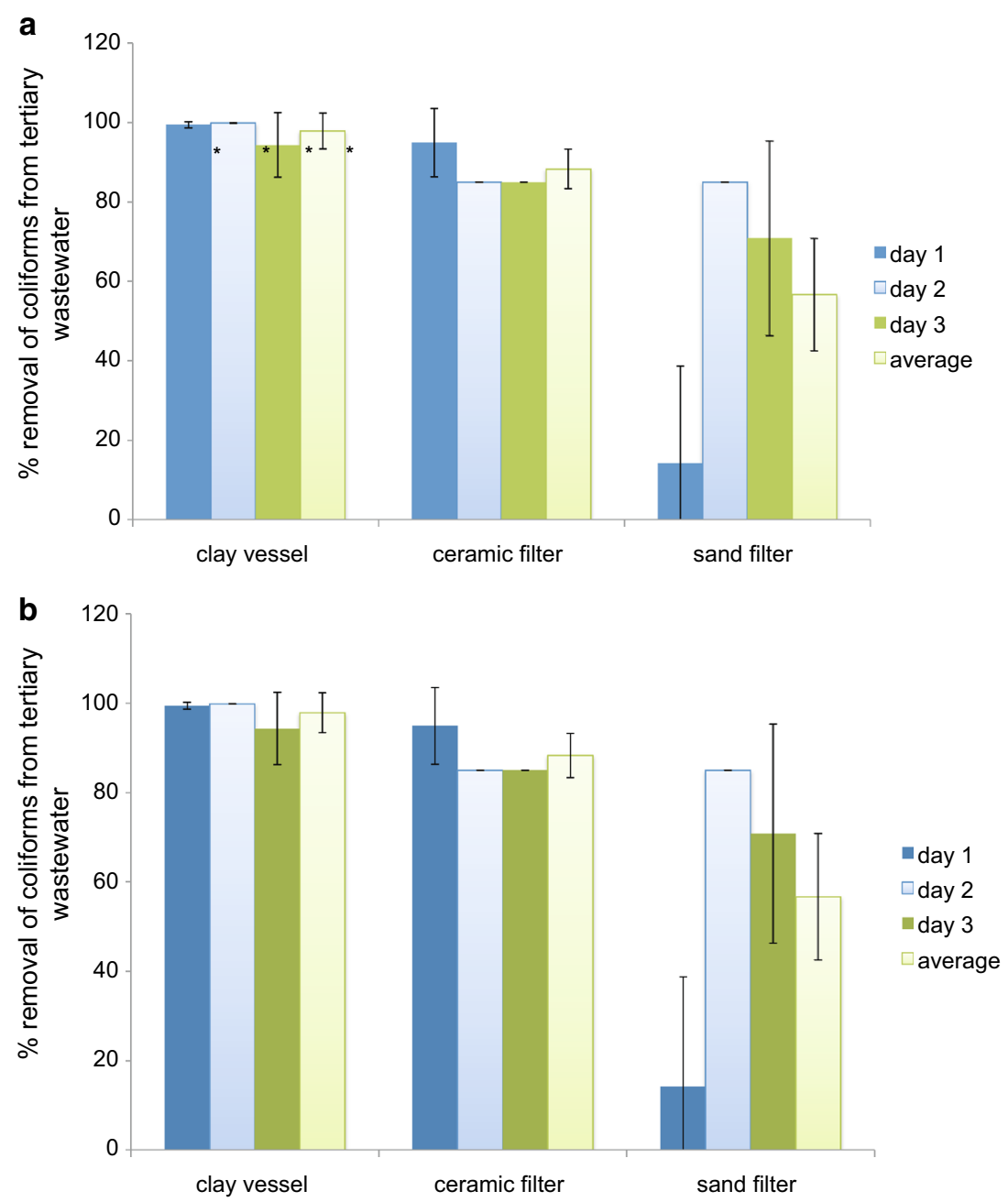
Table 4 Efficiency of retention of coliforms and $E$. coli by new and used filters $(n=3)$ with natural lake and spring waters

\begin{tabular}{llll}
\hline Source water & Filter type & $\%$ Removal coliforms & \% Removal E. coli $^{\mathrm{b}}$ \\
\hline Spring, Santa Catarina & Used ceramic candle & $91.4 \pm 10.4$ & $>86$ \\
& New ceramic candle & $>99.3$ & $>86$ \\
& Used clay vessel & $99.0 \pm 0.5$ & $>86$ \\
& New clay vessel & $98.7 \pm 0.9$ & $>86$ \\
Lake, San Pedro & Used ceramic candle & $>96.1$ & $>86$ \\
& New ceramic candle & $81.4 \pm 25.4$ & $>60$ \\
& Used clay vessel & $>96.1$ & $>60$ \\
& New clay vessel & $>96.1$ & $>60$ \\
\hline
\end{tabular}

a $\%$ Removal of coliforms was limited to $>99.3 \%$ and $>96.1 \%$ for non-detect samples due to initial concentrations; 240 and $46 \mathrm{MPN} / 100 \mathrm{~mL}$ for Santa Catarina and San Pedro, respectively

b \% Removal of E. coli was limited by in the initial concentrations; 13 and 4.5 MPN/100 mL for Santa Catarina and San Pedro, respectively distributors in the Atitlán region (Fig. 3). Distributors also identified three used filters of each type ( $>1$ year in use in households in lakeside communities) and new filters were exchanged with the families for used ones. The candle filter initial FIC for coliforms and $E$. coli were $240 \mathrm{MPN} /$ $100 \mathrm{~mL}$ and $13 \mathrm{MPN} / 100 \mathrm{~mL}$ in Santa Catarina source water and $46 \mathrm{MPN} / 100 \mathrm{~mL}$ and 4.5 MPN/100 mL for San Pedro source water, respectively. The ceramic candle filters demonstrated inconsistency in coliform retention for the new and used filters (Table 4). Used and new filters consistently removed FIBs from both source water types. No significant difference between filter types or new and used filters ( $p<0.05$, ANOVA), but $E$. coli was not detected in any of the filtrate samples, suggesting for mild (1-10 MPN/100 mL) to moderate levels (10-100 MPN/ $100 \mathrm{~mL}$ ). Given the size of $E$. coli and typical coliforms, at these moderate MPN present in raw water, size exclusion principles are likely responsible for retention. It will be critical evaluate the role of other mechanisms at more extreme conditions with natural lake waters. Dosing experiments with $E$. coli were not performed at the lakeside laboratory in order to not contribute additional contamination into lake waters without readily available treatment options. Ideally, similar studies would be conducted year round and with more contaminated lake waters.

In order to simulate higher initial surface concentration than in raw water at Santa Catarina and San Pedro, new filters were transported back to the US where experiments were repeated with surface waters with higher levels of coliforms and E. coli contamination. Challenge experiment controls had an average of 2067 and $1147 \mathrm{MPN} / 100 \mathrm{~mL}$ of coliforms and E. coli, respectively, on day 1 and, 1600 and $130 \mathrm{MPN} / 100 \mathrm{~mL}$ on the second day, achieving the much higher pathogen loading experienced in some regions of and time periods in lake waters at Atitlán. The clay pot vessels $(n=3)$ averaged $92.2 \%$ and $97.9 \%$ removal of coliforms on day 1 and day 2 , respectively, and while the ceramic candles $(n=3)$ removed 91.9 and $99.9 \%$ removal on day 1 and day 2. E. coli removal was $86 \%$ for both filter types on day 1 , while there was substantial break through for one of the clay vessels on day 2 with only $50 \%$ average removal (though the other two filters performed effective removal), while the candles average removal on day 2 was $97.5 \%$. This inconsistency suggests the importance of evaluating the performance of filters with lake water with initial high FICs ( $>100 \mathrm{MPN} / 100 \mathrm{~mL})$ over time to ensure that filter integrity remains intact. We cannot be certain that differences were not related to particularities of water quality parameters and future studies will include careful analysis of physicochemical parameters. Evidence in the literature indicates that both filter types should adequately protect against FIB if properly maintained (Mellor et al. 2014; Ren et al. 2013; Sobsey et al. 2008), although uncertainties remain with respect to viruses, protozoa, and toxins of concern (Murphy et al. 2010; van der Laan et al. 2014). Multiple modalities of treatment may be necessary to adequately protect POU in regions with impacted water bodies and little to no potable water infrastructure.

\subsection{Evaluation of filter flow rate}

Flow rates of each filter were determined and are presented in Table 5. No statistically significant differences could be determined between filter types and new and used filters. There was noted marked variability in flow rates between individual filters. Generally, the taller candle filters demonstrated faster filter rates for both new and used filters consistent with the literature (Schweitzer et al. 2013) and used filter rates were slower than new filter flow rates. As variation in filter flow rate could substantially impact ease and efficiency of use in households and strongly confound discrepancies in use and function of household filters (Sobsey et al. 2008), a more robust study must be carried out to determine consistency of variability in flow rates. 
Table 5 Flow rates of new and used filters $(n=3)$ challenged with natural lake waters

\begin{tabular}{llll}
\hline Ceramic candle & Flow Rate $(\mathrm{L} / \mathrm{h})$ & Clay vessel & Flow rate $(\mathrm{L} / \mathrm{h})$ \\
\hline Used 1 & 0.27 & Used 1 & 0.16 \\
Used 2 & 0.6 & Used 2 & 0.4 \\
Used 3 & 0.31 & Used 3 & 0.14 \\
New 1 & 0.36 & New 1 & 0.19 \\
New 2 & 0.4 & New 2 & 0.31 \\
New 3 & 0.66 & New 3 & 0.37 \\
Mean used & $0.39 \pm 0.8$ & Mean used & $0.23 \pm 0.14$ \\
Mean new & $0.47 \pm 0.16$ & Mean new & $0.29 \pm 0.09$ \\
\hline
\end{tabular}

Repeat "topping off" of raw water in the top of the filter may improve gravity-fed filtration rates (Schweitzer et al. 2013).

\subsection{Survey of range of FIC present at raw waters at Atitlán}

In May 2014, source waters for potable and recreational use and nonpoint source environmental waters were also tested for FIB. The FIC presented in Table 6 are substantially higher than FIC in source waters used in control challenge experiments. Previously collected data (unpublished from 2010; AMSCLAE Annual Monitoring Report 2013) have indicated the potential for severe levels of FIB at both San Pedro and Santa Catarina (>100 MPN/100 mL, WHO high level of risk). Since municipalities in the area inconsistently chlorinate the water, it will be important to more rigorously test the ability of both filter types to remove high levels of FIB from source waters at Lake Atitlán. Future experiments paired with longitudinal studies should be carried out over a variety of seasons and with and without chlorination prior to filtration since chlorination has the potential to alter surface characteristics of both filter types, impacting anti-microbial properties.

\subsection{Cyanobacterial toxin challenge experiments with clay vessel and ceramic candle filters}

Although the predominant cyanobacterial species (Limnoraphis) that have compromised the blooms thus far do not appear to have toxin-producing capabilities, other present bloom-forming species are present in lake waters (Anabaena, Aphanizomenon, Microcystis). Figure 9 shows a small bloom of Microcystis cf. botrys from the watershed. Preliminary spiking experiments were done with $10 \mu \mathrm{g} / \mathrm{L}$ microcystin LR, the most widely reported cyanotoxin in freshwater and the congener upon which WHO guidelines are established. Table 7 demonstrates potential promise for both filter types in removing moderate levels of microcystins from source waters.

The World Health Organization (WHO) recommends exposure of less than $1 \mu \mathrm{g} / \mathrm{L}$ and removal was consistently below this recommended level for both filter types. Little work has been done to evaluate POU filter ability to remove these cyanotoxins despite the worldwide prevalence of toxin-producing freshwater blooms in drinking source waters (Roegner et al. 2014). These findings are significant as microcystins are extremely stable compounds that cannot be eliminated by boiling or chlorination. Although the clay vessel and ceramic candles may have limited ability to remove viruses or other toxins (Murphy et al. 2010), they may prove sufficient for limited interventions to protect vulnerable populations against outbreak bloom scenarios, particularly if used in combination with other treatment methods. Mechanistically, given the pore size of both filter types is much too large for the removal to occur by size exclusion, the clay and carbon must be adsorbing free microcystin present in water. This finding is
Table 6 Survey of coliforms and E. coli (MPN/100 mL) in selected environmental waters at Lake Atitlán in May 2014

\begin{tabular}{lll}
\hline Water sources $^{\mathrm{a}}$ & MPN/100 mL coliforms & MPN/100 mL E. coli \\
\hline Tzununa & $<1600$ & $<1600$ \\
Catarata & $1.4 \mathrm{E}+04$ & $4.5 \mathrm{E}+03$ \\
San Buenaventura & $1.7 \mathrm{E}+04$ & $<1800$ \\
WWTP Panajchel & $6.1 \mathrm{E}+04$ & $3.7 \mathrm{E}+04$ \\
Rio Quizcab & $4.9 \mathrm{E}+05$ & $1.1 \mathrm{E}+05$ \\
Rio San Fransisco & $4.5 \mathrm{E}+03$ & $<1800$ \\
Lago Santa Catarina & $1.4 \mathrm{E}+02$ & $2.0 \mathrm{E}+01$ \\
Playa Panajchel & $2.2 \mathrm{E}+02$ & $2.0 \mathrm{E}+01$ \\
St. Cat. Ww eff. & $3.3 \mathrm{E}+05$ & $2.3 \mathrm{E}+05$ \\
St. Cat. WW inf. & $2.4 \mathrm{E}+07$ & $7.9 \mathrm{E}+06$ \\
\hline
\end{tabular}

${ }^{a}$ Includes water intake and nonpoint sources 


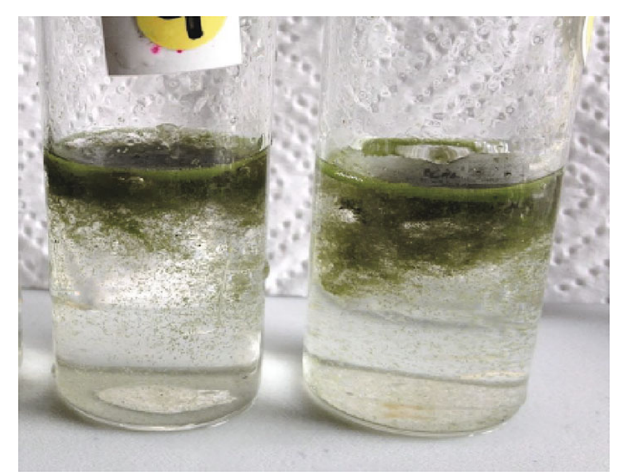

Fig. 9 Small cyanobacterial bloom of Microcystis cf. botrys found in riverine inputs in 2014

supported by evidence in the literature citing microcystin binding properties of activated carbon and clay (Huang et al. 2007; Morri et al. 2000). As such, it will be paramount to investigate saturation points over concentrations, time, water quality conditions, and across microcystin congener types. It should also be noted that pore size of filters are approximately the size of cyanobacteria. While the filters could physically remove cyanobacteria from raw water, caution should be made since lysing or accumulation of cyanobacterial cells might actually increase the amount of cyanotoxins in the filtrate; therefore, every effort should be made by households and community members to remove cells from raw water prior to filtration.

\section{Conclusions and implications for future CBPR work}

Community members of San Pedro de Atitlán showed an eagerness to engage in CBPR and to learn more about the link between water quality and health. This engagement proved to be an effective means to generate a broad array of data, including the ability of one locally available filter type (clay vessel) to substantially reduce household health risk from potable water over the course of 6 months. In addition, two filter types (clay vessel and ceramic candle) were shown to adequately and consistently remove moderate levels of FIB from potable waters from two different towns and sources. These two filter types showed preliminary success at removing spiked amounts of microcystins from deionized water. However, both the longitudinal household study and the controlled laboratory studies with various source waters identified two major problems: (1) potential inconsistency and variability in filter performance and (2) break through at severe levels of FIB, which have been reported in source waters. This inconsistency needs to be investigated further to determine potential variability in manufacturer quality or across water quality types. In particular, as since smaller bacteria, viruses, and microcystins cannot be removed by size exclusion alone, careful investigations into the involvement of aggregates, adsorption and silver catalysts for oxidative processes must be carried out to maximize efficacy in retention and ensure proper care and maintenance.

Further investigations over time and across water quality conditions are warranted, ideally with longitudinal household interventions greater than 1 year in length, paired with testing of source waters and controlled filter experiments with the same source waters. Microcystin removal from source lake waters by both filter types should be rigorously evaluated. The economic implications for households in terms of replacement of filters versus purchase of bottled water must be investigated, along with effectiveness of more than one treatment method. As women were identified as the primary providers and users of water resources at San Pedro de La Laguna during community forums, it is recommended that future work engage them directly in filter care, maintenance, and replacement.

Table 7 Microcystin LR retention from deoinized water spiked with initial concentration of $10 \mu \mathrm{g} / \mathrm{L}$ by filter type

\begin{tabular}{lllll}
\hline Filter & $\begin{array}{l}\text { Permeate average } \\
\text { (Envirologix QuantiPlate Kit) } \\
\text { Un/L }\end{array}$ & $\begin{array}{l}\text { Permeate } \\
\text { average (LC-MS/MS } \\
\text { ug/L }\end{array}$ & $\begin{array}{l}\text { Standard } \\
\text { deviation (LC-MS/MS) } \\
\text { ug/L }\end{array}$ & $\begin{array}{l}\text { Removal } \\
\text { efficiency } \\
\% \text { removal }\end{array}$ \\
\hline Clay vessel 1 & ND & 0.038 & 0.039 & 99.65 \\
Clay vessel 2 & ND & 0.032 & 0.030 & 99.71 \\
Clay vessel 3 & ND & 0.005 & 0.001 & 99.96 \\
Average clay & ND & 0.024 & 0.017 & 99.98 \\
Ceramic candle 1 & ND & 0.043 & 0.047 & 99.60 \\
Ceramic candle 2 & 1.2 & 0.115 & 0.14 & 98.93 \\
Ceramic candle 3 & ND & 0.023 & 0.023 & 99.79 \\
Average ceramic & $<1.2$ & 0.060 & 0.049 & 99.44 \\
Average control & 9.4 & 10.782 & 2.308 & Not applicable
\end{tabular}

No significant difference between filter types was observed 
Acknowledgements We extend thanks to the AMSCLAE Chemistry Lab, to Sololá campus of UVG, to Amigos del Lago and to Ms. Maria-Luz Sandoval for the assistance with logistics at the lake. Special thanks to Dr. Yanping Lin and Dr. Birgit Puschner for microcystin detection in DI water samples by LC-MS/MS. The support of the management of La Porta Hotel is greatly appreciated. The project would not have been possible without the generosity of Juan Carlos Cheves who provided the ceramic candle filters for the initial testing. Many thanks to all project participants from San Pedro, especially to Los Niños students and to members of COCODES organization. We also thank the Guatemalan and US participants of the training expedition of May 2014 for their help with filter testing. The work was supported by the UC Davis Blum Center for Developing Economies Poverty Alleviation Research to Action (PARA) project grants program, and partly by the United for Lake Atitlán Project (USAID Cooperative Agreement No. AID-520-A-12-00001).

\section{References}

Ahmed MS, Raknuzzaman M, Akther H, Ahmed S (2007) The role of cyanobacteria blooms in cholera epidemic in Bangladesh. J Appl Sci 7:1785-1789. doi:10.3923/jas.2007.1785.1789

Albert J, Luoto J, Levine D (2010) End-user preferences for and performance of competing POU water treatment technologies among the rural poor of Kenya. Environ Sci Technol 44:4426-4432

Bailie RS, Carson BE, McDonald EL (2004) Water supply and sanitation in remote indigenous communities-priorities for health development. Aust NZ J Public Health 28:409-414

Balazs CL, Morello-Frosch R (2013) The three R's: how community based participatory research strengthens the rigor, relevance and reach of science. Environ Justice. doi:10.1089/env.2012.0017

Barbour V, Clark J, Jones S, Peiperl L, Veitch E, Yamey G, Med P (2009) Clean water should be recognized as a human right. PLoS Med. doi:10.1371/Journal.Pmed.1000102

Bentley C, Laubach H, Spalter J, Ginter E, Jensen L (2004) Relationship of cryptosporidiosis to abdominal pain and diarrhea in Mayan Indians. Rev Inst Med Trop Sao Paulo 46:235-237. doi:10.1590/S0036-46652004000400011

Bielefeldt AR, Kowalski K, Summers RS (2009) Bacterial treatment effectiveness of point-of-use ceramic water filters. Water Res 43:3559-3565. doi:10.1016/j.watres.2009.04.047

Calderón Barrios M (2007) Municipal regional parks: a model of sustainable community development implemented in the Atitlan Lake watershed multiple-use reserve. Guatemala South America Conservation Region External Affairs Technical Publication 1:41-47

Carpenter SR (2008) Phosphorus control is critical to mitigating eutrophication. Proc Natl Acad Sci USA 105:11039-11040. doi:10.1073/pnas.0806112105

Casanova LM, Walters A, Naghawatte A, Sobsey MD (2012) Factors affecting continued use of ceramic water purifiers distributed to tsunami-affected communities in Sri Lanka. Trop Med Int Health 17:1361-1368. doi:10.1111/j.1365-3156.2012.03082.x

Chaudhuri M, Verma S, Gupta A (1994) Performance evaluation of ceramic filter candles. J Environ Eng 120:1646-1651

Clasen TF et al (2015a) Interventions to improve water quality for preventing diarrhoea. Cochrane Database Syst Rev. doi:10.1002/ 14651858.CD004794.pub3

Clasen TF et al (2015b) Interventions to improve water quality for preventing diarrhoea. Cochrane Database Syst Rev 10: CD004794. doi:10.1002/14651858.CD004794.pub3

Conley DJ et al (2009) Controlling eutrophication: nitrogen and phosphorus. Science 323:1014-1015. doi:10.1126/science.116 7755
Corman J et al (2015) Nutrient dynamics and phytoplankton resource limitation in a deep tropical mountain lake. Inland Waters 5:371-386

Dodds WK et al (2009) Eutrophication of U.S. freshwaters: analysis of potential economic damages. Environ Sci Technol 43:12-19

Drobac D, Tokodi N, Simeunovic J, Baltic V, Stanic D, Svircev Z (2013) Human exposure to cyanotoxins and their effects on health. Arhiv za higijenu rada i toksikologiju 64:119-130. doi:10.2478/10004-1254-64-2013-2320

Ford TE, Hamner S (2015) A perspective on the global pandemic of waterborne disease. Microb Ecol. doi:10.1007/s00248-0150629-0

Fraser ED, Dougill AJ, Mabee WE, Reed M, McAlpine P (2006) Bottom up and top down: analysis of participatory processes for sustainability indicator identification as a pathway to community empowerment and sustainable environmental management. J Environ Manag 78:114-127. doi:10.1016/j.jenvman.2005.04.009

Funari E, Testai E (2008) Human health risk assessment related to cyanotoxins exposure. Crit Rev Toxicol 38:97-125. doi:10.1080/ 10408440701749454

Gao C, Zhang T (2010) Eutrophication in a Chinese context: understanding various physical and socio-economic aspects. Ambio 39:385-393

Harvey TS (2012) Cyanobacteria blooms: Maya peoples between the politics of risk and the threat of disaster. Med Anthropol 31:477-496. doi:10.1080/01459740.2012.658588

Hoover E et al (2012) Indigenous peoples of North America: environmental exposures and reproductive justice. Environ Health Perspect 120:1645-1649. doi:10.1289/ehp.1205422

Huang WJ, Cheng BL, Cheng YL (2007) Adsorption of microcystinLR by three types of activated carbon. J Hazard Mater 141:115-122. doi:10.1016/j.jhazmat.2006.06.122

Johansson P, Knox-Nicola P, Schmid K (2015) The Waponahki tribal health assessment: successfully using CBPR to conduct a comprehensive and baseline health assessment of Waponahki tribal members. J Health Care Poor Underserved 26:889-907. doi:10.1353/hpu.2015.0099

Johnson CRS, Kraemer Diaz AE, Arcury TA (2016) What does it mean for something to be "scientific"? Community understandings of science, educational attainment, and community representation among a sample of 25 CBPR projects. Health Educ Behav. doi:10.1177/1090198116651038

Komárek J et al (2013) Polyphasic evaluation of Limnoraphis robusta, a water-bloom forming cyanobacterium from Lake Atitlán, Guatemala, with a description of Limnoraphis gen. nov. Fottea Olomouc 13:39-52

Larimer C, Ostrowski N, Speakman J, Nettleship I (2010) The segregation of silver nanoparticles in low-cost ceramic water filters. Mater Charact 61:408-412

Laubach HE, Bentley CZ, Ginter EL, Spalter JS, Jensen LA (2004) A study of risk factors associated with the prevalence of Cryptosporidium in villages around Lake Atitlan, Guatemala. Braz J Infect Dis Off Publ Braz Soc Infect Dis 8:319-323. doi:10.1590/ S1413-86702004000400008

Laukkanen M, Ekholm P, Huhtala A, Pitkanen H, Kiirikki M, Rantanen P, Inkala A (2009) Integrating ecological and economic modeling of eutrophication: toward optimal solutions for a coastal area suffering from sediment release of phosphorus. Ambio 38:225-235

Lonczak HS, Thomas LR, Donovan D, Austin L, Sigo RL, Lawrence N, Suquamish T (2013) Navigating the tide together: early collaboration between tribal and academic partners in a CBPR study. Pimatisiwin 11:395-409

Loo SL, Fane AG, Krantz WB, Lim TT (2012) Emergency water supply: a review of potential technologies and selection criteria. Water Res 46:3125-3151. doi:10.1016/j.watres.2012.03.030 
Mackey TK, Liang BA (2012) Integrating biodiversity management and indigenous biopiracy protection to promote environmental justice and global health. Am J Public Health 102:1091-1095. doi:10.2105/AJPH.2011.300408

Mellor J, Abebe L, Ehdaie B, Dillingham R, Smith J (2014) Modeling the sustainability of a ceramic water filter intervention. Water Res 49:286-299. doi:10.1016/j.watres.2013.11.035

Michen B, Diatta A, Fritsch J, Aneziris C, Graule T (2011) Removal of colloidal particles in ceramic depth filters based on diatomaceous earth. Sep Purif Technol 81:77-87

Mintz E, Bartram J, Lochery P, Wegelin M (2001) Not just a drop in the bucket: expanding access to point-of-use water treatment systems. Am J Public Health 91:1565-1570

Mittelman AM, Lantagne DS, Rayner J, Pennell KD (2015) Silver dissolution and release from ceramic water filters. Environ Sci Technol 49:8515-8522. doi:10.1021/acs.est.5b01428

Morri RJ, Williams DE, Luu HA, Holmes CF, Andersen RJ, Calvert SE (2000) The adsorption of microcystin-LR by natural clay particles. Toxicon Off J Int Soc Toxinol 38:303-308

Murphy HM, McBean EA, Farahbakhsh K (2010) A critical evaluation of two point-of-use water treatment technologies: can they provide water that meets WHO drinking water guidelines? J Water Health 8:611-630. doi:10.2166/wh.2010.156

Navichoc Sajquiy P (2007) Historia de San Pedro la Laguna, Sololá Maestria en Docencia Universitaria, Universidad de San Carols, Facultad de Humanidades, Escuela de Estudios Postgrados

O'Donahoo FJ, Ross KE (2015) Principles relevant to health research among indigenous communities. Int J Environ Res Public Health 12:5304-5309. doi:10.3390/ijerph120505304

O'Fallon LR, Dearry A (2001) Commitment of the National Institute of Environmental Health Sciences to community-based participatory research for rural health. Environ Health Perspect 109(Suppl 3):469-473

O'Fallon LR, Dearry A (2002) Community-based participatory research as a tool to advance environmental health sciences. Environ Health Perspect 110(Suppl 2):155-159

Oyanedel-Craver V, Narkiewicz S, Genovesi R, Bradshaw A, Cardace D (2014) Effect of local materials on the silver sorption and strength of ceramic water filters. J Environ Chem Eng 2:841-848

Paerl HW, Huisman J (2008) Climate. Blooms like it hot. Science 320:57-58. doi: $10.1126 /$ science. 1155398

Paerl HW, Huisman J (2009) Climate change: a catalyst for global expansion of harmful cyanobacterial blooms. Environ Microbiol Rep 1:27-37. doi:10.1111/j.1758-2229.2008.00004.x

Paerl HW, Fulton RS 3rd, Moisander PH, Dyble J (2001) Harmful freshwater algal blooms, with an emphasis on cyanobacteria. Sci World J 1:76-113. doi:10.1100/tsw.2001.16

Paerl HW, Hall NS, Calandrino ES (2011) Controlling harmful cyanobacterial blooms in a world experiencing anthropogenic and climatic-induced change. Sci Total Environ 409:1739-1745. doi:10.1016/j.scitotenv.2011.02.001

Pandit AB, Kumar JK (2015) Clean Water for developing countries. Annu Rev Chem Biomol Eng 6:217-246. doi:10.1146/annurevchembioeng-061114-123432

Paul BD, Demarest WJ (1984) Citizen participation overplanned: the case of a health project in the Guatemalan community of San Pedro la Laguna. Soc Sci Med 19:185-192

Rasch ED (2012) Transformations in citizenship: local resistance against mining projects in Huehuetenango (Guatemala). J Dev Soc 28:159-184. doi:10.1177/0169796X12448756

Rejmánková E, Komárek J, Dix M, Komárkova J, Girón N (2011) Cyanobacterial blooms in Lake Atitlan, Guatemala. Limnol Ecol Manag Inland Waters 41:296-302. doi:10.1016/j.limno.2010.12. 003
Reller ME et al (2003) A randomized controlled trial of householdbased flocculant-disinfectant drinking water treatment for diarrhea prevention in rural Guatemala. Am J Trop Med Hyg 69:411-419

Ren D, Colosi LM, Smith JA (2013) Evaluating the sustainability of ceramic filters for point-of-use drinking water treatment. Environ Sci Technol 47:11206-11213. doi:10.1021/es4026084

Rhodes SD, Malow RM, Jolly C (2010) Community-based participatory research: a new and not-so-new approach to HIV/AIDS prevention, care, and treatment. AIDS Educ Prev 22:173-183. doi:10.1521/aeap.2010.22.3.173

Richmond L (2013) Incorporating indigenous rights and environmental justice into fishery management: comparing policy challenges and potentials from Alaska and Hawai'i. Environ Manag 52:1071-1084. doi:10.1007/s00267-013-0021-0

Roegner AF, Brena B, Gonzalez-Sapienza G, Puschner B (2014) Microcystins in potable surface waters: toxic effects and removal strategies. J Appl Toxicol 34:441-457. doi:10.1002/jat.2920

Russell BD, Connell SD (2009) Eutrophication science: moving into the future. Trends Ecol Evol 24:527-528. doi:10.1016/j.tree. 2009.06.002 (author reply 528-529)

Salimi Y et al (2012) Is community-based participatory research (CBPR) useful? A systematic review on papers in a decade. Int $\mathbf{J}$ Prev Med 3:386-393

Saxton DI, Brown P, Seguinot-Medina S, Eckstein L, Carpenter DO, Miller P, Waghiyi V (2015) Environmental health and justice and the right to research: institutional review board denials of community-based chemical biomonitoring of breast milk. Environ Health 14:90. doi:10.1186/s12940-015-0076-x

Schmidt WP, Cairncross S (2009) Household water treatment in poor populations: Is there enough evidence for scaling up now? Environ Sci Technol 43:986-992. doi:10.1021/es802232w

Schweitzer RW, Cunningham JA, Mihelcic JR (2013) Hydraulic modeling of clay ceramic water filters for point-of-use water treatment. Environ Sci Technol 47:429-435. doi:10.1021/ es302956f

Servi AT, Frey D, Kang PK, Murcott S (2013) A holistic optimization framework for improving ceramic pot filter performance. Paper presented at the IEEE 2013 global humanitarian technology conference, San Jose, CA, USA

Simonis JJ, Basson AK (2011) Evaluation of a low-cost ceramic micro-porous filter for elimination of common disease microorganisms. Phys Chem Earth 36:1129-1134

Smith VH, Schindler DW (2009) Eutrophication science: Where do we go from here? Trends Ecol Evol 24:201-207. doi:10.1016/j. tree.2008.11.009

Sobsey MD, Stauber CE, Casanova LM, Brown JM, Elliott MA (2008) Point of use household drinking water filtration: a practical, effective solution for providing sustained access to safe drinking water in the developing world. Environ Sci Technol 42:4261-4267

Spector AY (2012) CBPR with service providers: arguing a case for engaging practitioners in all phases of research. Health Promot Pract 13:252-258. doi:10.1177/1524839910382081

Tobias JK, Richmond CA, Luginaah I (2013) Community-based participatory research (CBPR) with indigenous communities: producing respectful and reciprocal research. J Empir Res Hum Res Ethics 8:129-140. doi:10.1525/jer.2013.8.2.129

van der Laan $\mathrm{H}$ et al (2014) Bacteria and virus removal effectiveness of ceramic pot filters with different silver applications in a long term experiment. Water Res 51:47-54. doi:10.1016/j.watres. 2013.11.010

Weiss ES et al (2012) Sustaining CBPR partnerships to address health disparities in times of economic instability. J Health Care Poor Underserved 23:1527-1535. doi:10.1353/hpu.2012.0170 
Wilhelm SW et al (2011) The relationships between nutrients, cyanobacterial toxins and the microbial community in Taihu (Lake Tai), China. Harmful Algae 10:207-215. doi:10.1016/J. Hal.2010.10.001
Wright J, Gundry S, Conroy R (2004) Household drinking water in developing countries: a systematic review of microbiological contamination between source and point-of-use. Trop Med Int Health 9:106-117 